\title{
Libraries and Accessibility: Istanbul Public Libraries Case
}

Gül Yücel*

\section{Abstract}

In the study; the assessment of accessibility has been conducted in Istanbul public libraries within the scope of public area. Public libraries commonly serve with its user of more than 20 million in total, spread to the general of Turkey, having more than one thousand branches in the centrums and having more than one million registered members. The building principles and standards covering the subjects such as the selection of place, historical and architectural specification of the region, distance to the centre of population and design in a way that the disabled people could benefit from the library services fully have been determined with regulations in the construction of new libraries. There are works for the existent libraries such as access for the disabled, fire safety precautions etc. within the scope of the related standards. Easy access by everyone is prioritized in the public libraries having a significant role in life-long learning. The purpose of the study is to develop solution suggestions for the accessibility problems in the

Keywords: Library, accessibility, universal design, public library, Istanbul.

*Asst. Prof. Dr., Istanbul Gelişim University, Engineering and Architectural Faculty, Department of Architecture, Istanbul, Turkey. E-mail: gyucel@gelisim.edu.tr 
public libraries. The study based on the eye inspection and assessments carried out within the scope of accessibility in the public libraries subsidiary to Istanbul Culture and Tourism Provincial Directorate Library and Publications Department within the provincial borders of Istanbul. The arrangements such as reading halls, study areas, book shelves etc. have been examined within the frame of accessible building standards. Building entrances, ramps and staircases, horizontal and vertical circulation of building etc. have been taken into consideration within the scope of accessible building standards. The subjects such as the reading and studying areas and book shelf arrangements for the library have been assessed within the scope of specific buildings. There are a total of 34 public libraries subsidiary to Istanbul Culture and Tourism Provincial Directorate on condition that 20 ea. of them are in the European Side.

\section{INTRODUCTION}

Public libraries being the most important resource for the society to reach information are the information centers aiming to reach every section of the society with its network expanding to the smallest settlements. As it is emphasized in United Nations Educational, Scientific and Cultural Organization UNESCO Public Library Manifesto (1994), it is the local information center providing the information to the users voluntarily (UNESCO, 2015). Giving support in reaching service to those having problems in reaching information without any discrimination is among their duties. They aim to give service to every section of the society with their flexible physical structure and content that could renew itself in parallel to the changing usage and that is in accordance with the contemporary needs. The provision of every kind of conditions necessary in the supply of information and access to information is the basis for the libraries. Physical sufficiency, collection being in a status that is accessible for every level and competent personnel service are the elements affecting the benefit from the library.

Considering accessibility in a physical meaning and in a wider meaning out of the principles dependent on the user characteristics shall positively affect the libraries' property of being a local information resource. For instance; the conditions such as arranging the usage areas of the children in parallel to the perception structure, considering the ergonomic conditions in physical dimensioning, providing the expansion of the handicapped usage as visual, audible and tangible surface in the library, providing easy, defined descriptions, directions and usage in which the difference of education level is taken into consideration etc. shall also have an encouraging role as well as facilitating the process of the society for reaching information. The precautions and spatial arrangements to be taken within this 
direction in the new library buildings are in an easily applicable status. Many physical, structural etc. difficulties could be existent against the new arrangements regarding the usage and provision of the necessary conditions in physical terms in the existent libraries.

\section{ACCESSIBILITY AND LIBRARIES}

Accessibility could be defined as the methods used in access to the elements such as the product, activity, service and building related to the physical social, economical, environmental etc. levels to be perceivable, available and usable by everyone. Accessibility is not only limited to the physical conditions. Relating only the disable to accessibility is also not sufficient. It could be thought that it covers all the related areas taking the benefit of each person from the fundamental rights and freedoms as the basis. The difficulties in reaching the fundamental rights taking place in The Universal Declaration of Human Rights (1949) could also be related to the accessibility from a point of view.

Access to the libraries within the scope of "Participation to the cultural life, resting, free time activities and sport activities" and taking the necessary precautions within the scope of the provision of "access to the information with freedom of thought and expression" take place in "Contract On the Rights of Persons with Disabilities," (Engellilerin Haklarına İlişkin Sözleşme, 2009) approved in 2009 as International Contract.

In the Law on the Disability, accessibility is expressed as "the buildings, open areas, transportation and information services and the information and communication technologies to be safely and independently accessible and usable by the disabled" (Engelliler Hakkında Kanun, 2005). The process of adaptation to the law regarding being accessible for the disabled in the existent buildings in the same Law in which the libraries also take place within the scope of the buildings giving service as open for public have been determined as eight years. Accessibility could also be related to the Universal Design in the process of building places physically. Seven principles (equitable use, flexibility in use, simple and intuitive use, perceptible information, tolerance for error, low physical effort, size and space for approach and use) determined within the scope of the Universal Design principles include the fundamental issues regarding the physical elements in terms of accessibility (Story, Mueller, \& Mace, 1998). The library should be accessible for all people in the country. The users can be characterized with different age, culture, education and other specifications such as being physical or mental difficulties. In the designing process, all user criteria should be 
taking consideration for success of accessibility. According to universal design, equitable use shows that design should be useful and marketable to people with different abilities. Flexibility in use is also related with easy use. The design should be accommodates a wide range of individual preferences and abilities. Low physical effort is another principle that important for accessibility. The design should be used efficiently and comfortably and with a minimum fatigue (Story et al., 1998). Making accessible library is depending to design and design parameters. There are some studies and assessment checklists for accessible library. Most of accessibility studies are related directly person for disable. But on the other hand universal design criteria's is more inclusive and related with wider section of the population.

The library accessibility checklist for persons with disabilities, progressed by International Federation of Library Associations and Institutions IFLA (2005) is settled physical access, media format and service and communication mainly (IFLA, 2005) (Table 1). The physical access focuses outside library, getting into the library and access to materials and services. Media formats topic is related special media for person with disabilities. Service and communication is related with training staff, special service for and providing information to disabled patrons. The accessibility of library as physically is related architectural design directly. Taking consideration universal design criteria into designing process is important for making accessible library. United States Access Board's, ADA Accessibility Guidelines (ADAAG) is included library buildings also, including reading and study areas, stacks, reference rooms, reserve areas, and special facilities or collections (ADA, 2016). American Library Association ALA has studies titled "ADA and Libraries" and with The Association of Specialized and Cooperative Library Agency ASCLA has developed "Library Accessibility -What You Need to Know" toolkit series of fifteen tipsheets to help librarians in all types of libraries understand and manage access issues (ALA, 2016). Disability Law Center (DLC) has created an (Americans with Disabilities Act) "ADA Checklist" for libraries, which is related with physical aspects, including drinking fountains, telephones, lavatories, stalls, doorways and passages, rooms and spaces, horizontal circulation, reading and studying areas, entrance, ramps, route of travel and parking and drop-off areas (DLC,2016). The checklist is also parallel with IFLA (2005) sample. In the same way, it also takes place in the Contract Regarding the International Disabled Rights in which universal design could be benefited. 
Table 1. Access to libraries for persons with disabilities - Checklist Summary IFLA (IFLA, 2005)

\begin{tabular}{|c|c|c|}
\hline \multicolumn{3}{|c|}{ Access to libraries for persons with disabilities - Checklist } \\
\hline \multirow[t]{4}{*}{$\begin{array}{l}\text { Physical } \\
\text { access }\end{array}$} & $\begin{array}{l}\text { Outside the } \\
\text { library }\end{array}$ & $\begin{array}{l}\text { Sufficient parking space, distance to main } \\
\text { entrance, clear signpost, adequate lighting, } \\
\text { smooth and non-slip surface at the } \\
\text { entrance, if needed suitable ramp with } \\
\text { both side railing, entry phone for deaf } \\
\text { users at the entrance. }\end{array}$ \\
\hline & $\begin{array}{l}\text { Getting into } \\
\text { the library }\end{array}$ & $\begin{array}{l}\text { Sufficient space in front of the door, } \\
\text { Entrance door wide enough for } \\
\text { wheelchair, No doorsteps, Glass doors } \\
\text { marked to warn visually impaired } \\
\text { persons, Suitable security checkpoints, } \\
\text { Stairs and steps marked with a contrasting }\end{array}$ \\
\hline & & $\begin{array}{l}\text { color, Pictogram signs leading to } \\
\text { elevators, Well lighted elevators with } \\
\text { buttons and signs in Braille and synthetic } \\
\text { speech, Elevator buttons reachable from a } \\
\text { wheelchair }\end{array}$ \\
\hline & $\begin{array}{l}\text { Access to } \\
\text { materials and } \\
\text { services }\end{array}$ & $\begin{array}{l}\text { The physical space, Toilets, Circulation } \\
\text { desk, Reference/information desk, } \\
\text { Children department, Department for } \\
\text { person with reading, hearing and other } \\
\text { disabilities }\end{array}$ \\
\hline \multirow[t]{2}{*}{$\begin{array}{l}\text { Media } \\
\text { Formats }\end{array}$} & $\begin{array}{l}\text { Special } \\
\text { medias for } \\
\text { person with } \\
\text { disabilities }\end{array}$ & $\begin{array}{l}\text { Special media formats for persons with } \\
\text { disabilities }\end{array}$ \\
\hline & & Accessible computers for public use \\
\hline $\begin{array}{l}\text { Service } \\
\text { and } \\
\text { commun } \\
\text { ication }\end{array}$ & Stuff Training & $\begin{array}{l}\text { Organization of staff meeting for library } \\
\text { users; Information distribution to staff } \\
\text { about library services to specific disability } \\
\text { groups; Staff orientation programs }\end{array}$ \\
\hline
\end{tabular}

Special Home delivery services, Outreach services, services to Reading and scanning services, regular disabled consultations for reading disabilities

patrons

How to For visually impaired persons, deaf or provide hearing impaired persons, persons with information reading difficulties (persons with dyslexia to disabled or weak readers), persons with physical patrons disabilities and cognitively disabled persons

Cooperating A formal invitation to cooperate on with various projects, A joining "brain disability storming" meeting, Planned activities in organizations the library, Regular meetings with and organizations and/or individual patrons individuals to discuss future initiatives, Joining development projects and joining media contacts 


\section{PUBLIC LIBRARIES}

The design of the public libraries in integration with the universal design criteria and valid spatial regulations is significant in its being an information center serving as a whole with its content and administrative structure. Subjects such as regulations in building standards, spatial organization research and material opportunities affect the libraries positively in physical terms. Apart from the opportunities in new library formations, improvement works to be done within the scope of accessibility in the harmony of the existing buildings to the current situation. It might be possible to do these kinds of studies together with the improvements in the factors which are structural and non-structural.

Rules and principles of the physical regulations to provide accessibility to all buildings and nearby for the disabled and people who have limitation of movement have been identified in a detailed way with the standard (TS 9111) published in the title "The requirements of accessibility in buildings for people with disabilities and mobility constraints" (TSE, 2011). The subject regulations make contribution as an important input in the period of designing and applying new building. It is possible to handle accessibility as a system of structured environment outside the building, buildings and transportation physically. In terms of accessible environment, it could be ordered as pedestrian ways, ramps, stairs, crosswalks, parking areas, open and green areas. In terms of accessible building, internal regulations of the building, regulations related to the buildings within special use (hospital, library, transportation, etc.) and existing buildings might be considered (TSE, 2011). The areas related to transportation and public transportation are from the areas where accessibility is dealt in informing-pointing (TSE, 2011). Service areas such as entrance to buildings, the entrance door, ramp and staircase regulations, horizontal and vertical circulate inside the building, corridor and halls, toilet and kitchen are in subject in terms of accessible building. It is possible to extend the accessibility factors within buildings according to the function of the building.

Public libraries are an important center in disseminating information to society. Its existence during the historical process, basis developed with the Republican era, its existence and development in the structure of community centers in the process following the foundations of community centers are the processes affecting the maintenance of duty as center which provides the need of information of the society in today's settlements. Public library is open to every type of user. It is the 
center providing accessibility to opportunities such as improving the habit of reading in society, reaching information people need and participating in cultural activities.

"In The Regulations of Public Libraries" (Halk Kütüphaneleri Yönetmeliği (2012), these duties taking place in library duties reveal and highlight the importance and place of public libraries in social life. Apart from benefiting from books, it might be considered as the local information focus undertaking an important role in the development of social life and sociocultural structure. Within this scope, it comes forward that evaluating the accessibility in public libraries with all dimensions is important.

\section{PUBLIC LIBRARIES IN TURKEY}

There are 1121 public libraries subject to The Ministry of Culture and Tourism, General Directorate of Libraries and Publications (KYGM) all across the country (KYGM, 2015). 34 of them are in Istanbul. 6 of the libraries in Istanbul serve as the district public library directorate, 10 of them being subject to the district public library directorate. 6 of the libraries are children's library. In public libraries where the number registered members all across the country exceeds one million, total number of users is getting closer to 21 million according to the statistics of 2014 (KYGM, 2015), (Table 2). The number of children and adults is close to each other in public libraries (TÜİK, 2014).

Table 2. Public Library Statistics according General Directorate of Libraries and Publications (KYGM) (KYGM, 2015)

\begin{tabular}{lr}
\hline \multicolumn{2}{l}{ Public Library Statistics $\mathbf{2 0 1 4}$} \\
\hline Public library & 1121 \\
Book & 17111825 \\
User & 20787765 \\
Registered User & 1209766 \\
Lending material & 7600807 \\
\hline
\end{tabular}

In public libraries where the number of books exceeds 17 million, the material being lent is close to 8 million (KYGM, 2015), (Table 2). The books are generally in the areas of literature and rhetoric, social sciences and history (TÜİK, 2014). Libraries are not only limited to utilizing the books and material other than books but also the focus of using library is enhanced with the cultural activities. Reading days, creative drama and reading activities are organized in the activity points in or outside the library; in this way; the processes of book, library, and acquisition of knowledge are shared with the society.

In the process of choosing a place for the public libraries of which building principle and standards are identified by (Halk 
Kütüphaneleri Yönetmeliği (2012) In The Regulations of Public Libraries the condition has been attached which says the settlement population should be 50 thousand at least. Minimum sizes (branch minimum $500 \mathrm{~m}^{2}$, minimum for the center library $1200 \mathrm{~m}^{2}$ ) for branch or center library buildings have been determined with the same regulations. In the regulations highlighting the disabled users benefiting from library services completely, in the part of building and equipment principle and standards, one reader table and four chairs have been proposed for every eight square meter area in reading halls. Nowadays, the distribution and sharing of the information sources in electronic media show increase and also the desire to reach the pressed information sources still stands. Besides, not only reaching the information resource but also the inclination to use the information center increase. Young population in the education period uses the libraries both as the information resource and information home. They also benefit from the study areas and internet opportunities. Updating the public libraries to meet the need of today's world will support the information exchange, being together and studying together.

\section{CASE STUDY: İSTANBUL PUBLIC LIBRARIES AND ACCESSIBILITY}

The study evaluates the public libraries within the provincial borders of Istanbul in physical scope in terms of building accessibility. The assessment is based on accessibility to library. The literature review of the study contains the process of observation and examination in situ and interview with the related units. In situ examination has been done in public libraries subject to Istanbul Provincial Directorate of Culture and Tourism Library and Publications Branch within the provincial borders of Istanbul. It includes the determination and evaluations based on external observation. The physical access evaluated that according to accessible buildings standards and (IFLA, 2005) checklist for person with disabilities and TS 9111 (TSE, 2011). All of them are parallel with Americans with Disabilities Act (ADA) Accessibility Guidelines for Buildings and Facilities also (ADA, 2016).

In the study, the entrance to building, ramp and staircases, horizontal and vertical circulation etc. have been taken into consideration in the evaluation within the scope of accessible building standards and IFLA (2005) checklist in general. The subjects such as reading, study areas and book shelf arrangements for the library have been assessed within the scope of specifical buildings. Historical building using as library is also assessed in the study at same scope and concept of 
reusing historical buildings. In situ examination has been done in September- December 2015.

Istanbul Public Libraries: There are 34 public libraries being subject to Istanbul, the Directorate of Culture and Tourism in total. 6 of them are children library. Libraries are in a situation settled inside the building having different typology such as with different institutions, independent building, and historical building. Variability in the selection of the examined sample has been paid regard such as being in different areas, use of historical building, use of independent building and accessory use with other public institutions. 13 libraries in total have been examined in situ as 6 being in the Anatolian side out of 34 libraries subject to Istanbul Directorate of Culture and Tourism (Figure 1). 6 of the samples are directorate and 2 are children libraries. 2 of the selected libraries have been placed in the historical buildings (Figure 2). One of the samples is in the historical peninsula.
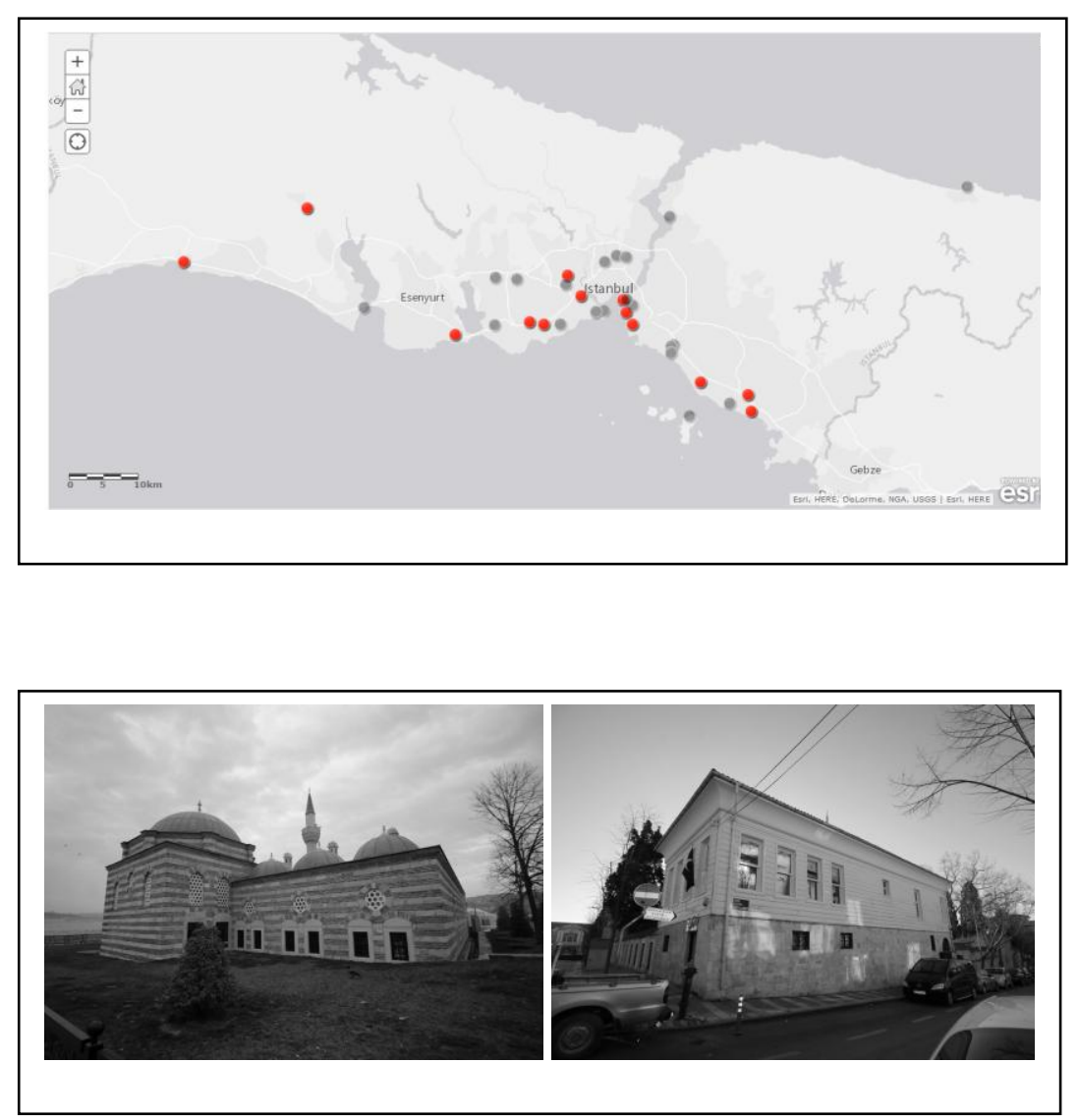

Public Libraries specification: The level of research is in the primary and high school level mainly in the examined libraries. Primary and high school students use public libraries mainly in order to utilize internet, do homework and study. The age range of users differs in the areas where libraries take place. Different
Figure 1. Map of Public Libraries in Istanbul (Red: examined, Grey: not examined)

Figure 2. Public Library in Historical Buildings 2 of the selected libraries have been placed in the historical buildings (Yücel, 2015) 
profile in the age range affects the use and regulations depending on the physical conditions for each library. The crowding of the use of libraries changes from period to period and generally it increases in education periods. The libraries except for two which were examined serve during the work hours every day except for Sunday. The time of staying in library of the library users differ depending on use type. The users loan book exchange might be considered as the users with the shortest time. It is followed by the ones who come to do research and use as study area. It has been stated that there are readers who use the library whole day with the aim of preparing for the exam. The type of use also differs according to the place of library.

Building accessibility: The entrance to building, ramp and staircases, building entrance door, horizontal and vertical circulation, book shelves and table regulations in reading halls have been dealt with in the scope of accessible building standards in physical terms in the evaluation. In the samples, there are samples involving the suitable regulation for the disabled access in the entrance of building; also there are samples having difficulties in terms of improving the situation by the place (Figure 3).

Figure 3. Public Library Entrance Samples (Yücel, 2015)

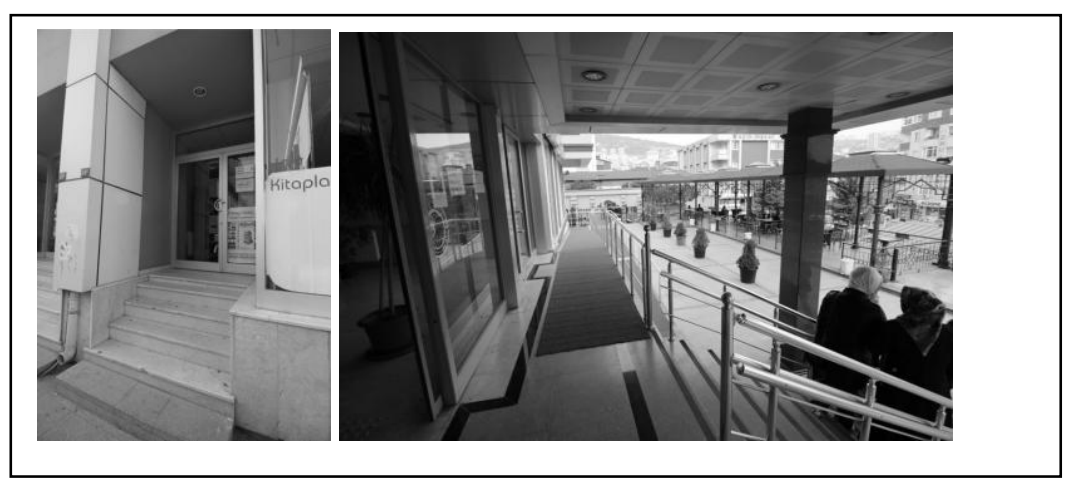

Tactile paving application is seen in the samples examined but not common. It has been encountered more in the buildings in common use. In the samples where building entrance is not on the same level with the pavement, samples having ramp application outside the staircase have been observed. In the situation where there is not the opportunity for required area in ramp regulation, it has been detected that there is difficulty in providing the standards. However, solution has been developed to the access difficulty to the building originating from these elevation differences in libraries having a second entrance. Even though the situation of leaving enough platform is seen in some samples in the relation of entrance doors with entrance platform, pavement distance and building settlement especially in the city samples might make it harder. The location, the existence of 
enough open area such as garden affects the arrangement of the building entrance platform positively.

In the examination of horizontal and vertical circulation, although circulation is simple and defined for the libraries in independent buildings, different situations might emerge in common use conditions. Especially the situation that the library is located upstairs except for the basement affects the access and recognition negatively. Supporting the library with guidance and halls in distinctive and apparent way will be useful for the users. Especially guidance in the case with common use with different function other than education, culture and art etc. should be supported with enough tools. The location and physical structure of the ladders are convenient in the samples with independent building usage in the arrangement of the vertical circulation tools, ladders, ramps and elevators; and the existence of the equipment such as elevator etc. that may be necessary changes depending on the age of the structure. In some part of the examined samples, the elevators added later have been regulated by focusing on the disabled. In common use with other units and in new structures, there are elevators in enough equipment. The situation of adding this type of vertical circulation equipment later depending on the date of built of the structure brings out the necessity to regulate with the interventions such as structural improvement in the structure and measures with fire focus. In this process, the ownership becomes important and affects the process.

Library interior design: In most of the samples, even though the table heights and suitable spaces between tables are considered sufficient in reading and studying areas, the sufficiency of accessibility to reading and studying areas should be preferential. Dense shelve order developed in area insufficiency creates difficulty in use and makes it harder to be in the required standards of the study areas. Book shelves have been solved integrated with reading halls (Figure 4, 5, 6).

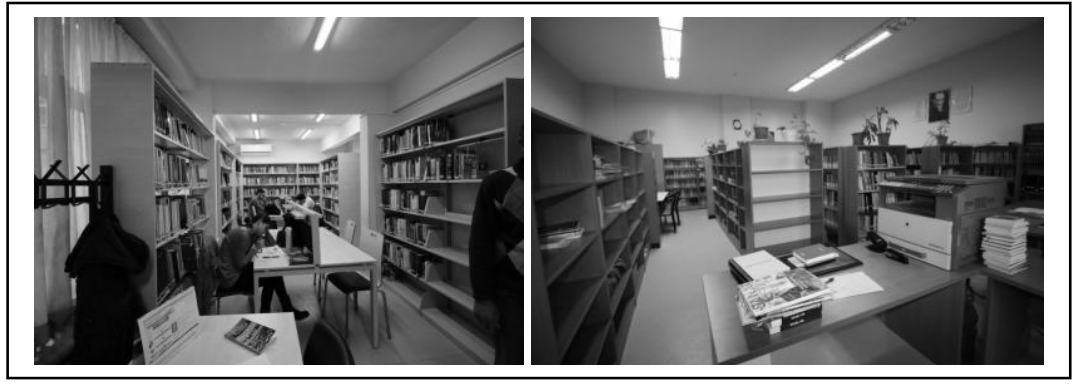

Although book shelves and study tables are in the same hall in some samples, separate grouping has been done. It has been observed that the separation of reading and studying halls is not
Figure 4. Reading hall view bookshelves and tables arrangement (Yücel, 2015) 
Figure 5. Reading hall view bookshelves and tables arrangement (Yücel, 2015)

Figure 6. Bookshelves Arrangement the bookshelves should be arranged enough width (Yücel, 2015) done in the library samples involving one hall. Although shelf distances are sufficient in terms of accessibility to book shelves in most of the samples, in some samples sufficient blanking order could not be made between shelves because of the narrow area.
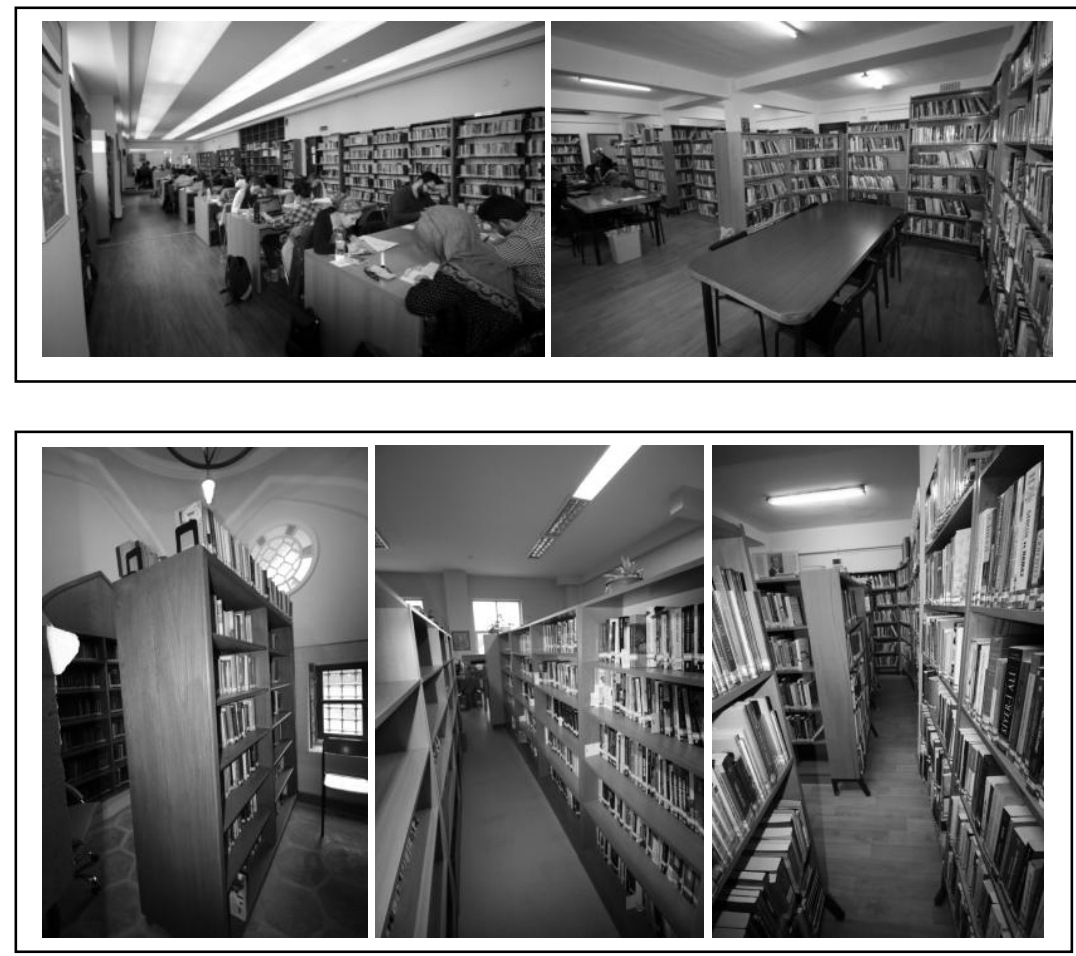

The sufficiency of circulation area in reading and studying halls arranged with shelves should be controlled. The fact that the fixed partials in the structure in the samples in historical structure meet the needs of today's poses a challenge in cases requiring especially wide use areas. Therefore, it is important that special analysis of spatial arrangement and furniture design according to the features of the place in the use of these kind of buildings. Mobile solutions other than the special closed area and desktop computer might provide flexibility in the use of internet. It has been observed that the activity areas are limited in most of the samples. It could be prescribed that it is arranged in the ground floor in multi-storey libraries and it is open to these kind of use by creating flexible use areas inside the library. The location, access and evacuation convenience of the activity area should be considered.

\section{CONCLUSION}

Public libraries are important sources in accessing information which serve in the smallest settlement with the number libraries exceeding a thousand serving every level of society and having a number of user exceeding twenty million. It is preferential to provide accessibility in physical, social and environmental components during the process of being in inclusive feature of all 
the society. In this way, the barrier of the physical structure in reaching information easily in every age and every situation will disappear. In regulations to be done for the existing libraries, first the regulations of accessing to the building and inwards building regulations are important. Ramp regulation in suitable conditions should be considered in accessing the building. It has priority to providing the required standards in terms of accessibility building circulation and providing the suitable opening way and size to entrances in doors in the improvements to be done. Use regulations and accessibility opportunities in ground floors should be developed for the conditions that improvements in vertical circulation elements are not possible. The applications such as pointing and perceivable surface not involving large scale interventions are in easily applicable quality for the existing libraries.

It should be in the forefront that dimensional and cycle opportunities are in the suitable size and disposal order for the user of every level in the indoor movable furniture. The sizes and placing of furniture should have the opportunity of arranging in a way open to flexible use depending on the features of use type, the structure of building and user. In the process of realizing the suitable regulations for today's conditions in the existing public libraries, structural sanitization, providing the fire safety and structural precautions in the scope of preparation for the disaster should be planned together. It has priority to arrange the children parts in public libraries for users in suitable physical condition and location.

There are some difficulties in libraries which is settled in historical building. Interior arrangements and some horizontal and vertical circulations standards may be restricted because of physical conditions. The originality of building should be protected during the adaptation progress in the historical buildings. The capacity of library should be take into account while reusing decision for historical buildings.

Public libraries are the centers including utilization of publication, reaching information and also social integration and cultural exchange. It should be supported with spatial arrangements to strengthen the social ties. The location of public libraries in the settlement affects the use and the user. Being located near the cultural center, museums, social center and education structures etc. will affect its use positively. Taking precautions to identify and decrease the large scale risks integrated with the environment and building is one of the factors affecting the safety of user, collection and personnel. The personnel of public library should be supported with education in parallel with the tools and changing habits of use of the day. 


\section{REFERENCE}

Americans with Disabilities Act, ADA. (2016). Accessibility Guidelines (ADAAG), https://www.access.board.gov/attach ments/article/1350/adaag.pdf [Accessed 13 November 20 16]

American Library Association, ALA. (2016). (Americans with Disabilities Act) ADA and Libraries, <http://www.ala.org/t ools/ada-and-libraries> [Accessed 13 November 2016]

Disability Law Center. (2016). The Americans with Disabilities Act, ADA. Checklist.Libraries, <http://disabilitylawcenter.o $\mathrm{rg} /$ wpcontent/uploads/publications/ada\%20checklists/A DA\%20Library\%20Checklist.pdf> [Accessed 07 November 2016]

Engelliler Hakkında Kanun. (2005). Kanun No: 5387/2005. (Resmi Gazete, Sayı: 25868, Tarih: 7 Temmuz 2005)

Engellilerin Haklarına İlişkin Sözleşme. (2009). 3.12.2008 tarihli ve 5825 sayılı Kanun. (Resmi Gazete, Sayı: 27288, Tarih:14 Temmuz 2009)

Halk Kütüphaneleri Yönetmeliği. (2012). Halk Kütüphaneleri Yönetmeliği. (Resmi Gazete, Sayı: 28170, Tarih:11 Ocak 2012).

Kültür ve Turizm Bakanlığı Kütüphaneler ve Yayımlar Genel Müdürlüğü, KYGM. (2015). Bakanlığa Bağlı Halk Kütüphaneleri 2014 Yıll.İstatistik Bilgileri, <http://www.ky gm.gov.tr/TR,134508/halk kutuphaneleri-verileri.html> [Accessed 02 September 2015]

The International Federation of Library Associations and Institutions, IFLA. (2005). Access to libraries for persons with disabilities - Checklist, By Birgitta Irvall and Gyda Skat NielsenThe Hague, IFLA Headquarters (IFLA ProfessionalReports:89)<http://www.ifla.org/files/assets/ hq/publications/professional-report/89.pdf> [Accessed 07 November 2016]

Story, M.F., Mueller, J.L., Mace, R.L. (1998). The Universal Design File, Designing for People of All Ages and Abilities. NC State University, The Center for Universal Design, <https://www. ncsu.edu/ncsu/design/cud/pubs_p/pudfiletoc.htm> [Accessed 20 November 2015]

Türk Standartları Enstitüsü TSE (2011) “Özürlüler ve Hareket Kısıtlılığı Bulunan Kişiler İçin Binalarda Ulaşılabilirlik Gerekleri", TS 9111 (2011) TSE, TS 9

Türkiye İstatistik Kurumu, TÜİK. (2014).Türkiye Kültür İstatistikl eri 2013. Ankara

UNESCO (2015). Public Library Manifesto (1994) <http://www.u nesco.org/webworld/libraries/manifestos/libraman.html> [Accessed 25 September 2015] 


\section{Resume}

She graduated from Istanbul Technical University, Architectural Faculty in 1985. In 1988, she received master's degree in Istanbul Technical University, Institute of Science and Technology Department of Architecture and Urbanism, Building Technology Program. She completed her doctorate in Ylldiz Technical University, Institute of Science and Technology, Department of Architecture, with a thesis entitled "Earthquake and Physical and Social Vulnerability Assessment Model for Settlements: Case Study Avcllar District". In 2013 she worked as an Assistant Professor at Namık Kemal University, Faculty of Fine Arts, Design and Architecture, Department of Architecture. She has been working in Istanbul Gelişim University as an academic staff of department of Architecture since 2015. 